\title{
ZC3H7B Gene
}

National Cancer Institute

\section{Source}

National Cancer Institute. ZC3H7B Gene. NCI Thesaurus. Code C111980.

This gene plays a role in binding to rotaviral proteins. 